Vol. 6 No.1 Tahun 2021

Jurnal Nusantara

E-ISSN : 2528-0929 P-ISSN : 2549-5291

Aplikasi Manajemen Bisnis

\title{
Peranan Customer Satisfaction dan Customer Commitment terhadap $e$ - WOM dalam Pengguna Aplikasi Gopay di Yogyakarta
}

Valinda Carolina De Quelyu ${ }^{1}$, Singgih Santoso ${ }^{2}$

Universitas Kristen Duta Wacana ${ }^{1,2}$

Surel: singgih.santoso@gmail.com

https://doi.org/10.29407/nusamba.v6i1.14533

\section{Informasi Artikel}

Tanggal masuk :

3 Juli 2020

Tanggal revisi :14

Desember 2020

Tanggal diterima:

4 April 2021

\begin{abstract}
Customer satisfaction that takes place consistently will make consumers have a commitment to a brand and can further encourage promotion through word of mouth activitie. The purpose of this study was to determine the effect of customer satisfaction on customer commitment, and the impact on consumer commitment to do e-wom activities. This research uses Gopay service as the research object and gender as the moderating variable. With the survey method on 377 respondents and the structural model testing hypotheses process, the results show that consumer satisfaction has a positive effect on consumer commitment, and consumer commitment has a positive effect on e-WOM activities; while gender is proven to moderate the relationship between these variables.
\end{abstract}

Kata Kunci: Customer Satisfaction, Customer Commitment, e-Word of Mouth, Gender

\begin{abstract}
Abstrak
Kepuasan pelanggan yang berlangsung secara konsisen akan membuat konsumen mempunyai komitmen pada sebuah merek dan selanjutnya dapat mendorong promosi lewat kegiatan word of mouth (wom). . Tujuan penelitian ini untuk mengetahui pengaruh kepuasan pelanggan terhadap komnitmen pelanggan, serta dampaknya pada keinginan konsumen melakukan kegiatan e-wom. Penelitian menggunakan layanan Gopay sebagai obyek penelitian dan gender sebagai variabel moderasi. Dengan metode survei pada 377 responden dan proses pengujian model struktural, hasil menunjukkan kepuasan konsumen berpengaruh positif pada komitmen konsumen, dan komitemen konsumen berpengaruh positif pada kegiatan $e$-WOM; sedangkan gender terbukti memoderasi hubungan antar variabel tersebut.
\end{abstract}

Kata Kunci: Kepuasan Pelanggan, Komitmen Pelanggan, electronic Word of Mouth, Gender

1.

De Quelyu, Valinda Carolina, and Singgih Santoso. 2021. "Peranan Customer Satisfaction Dan Customer Commitment Terhadap E-WOM Dalam Pengguna Aplikasi Gopay Di Yogyakarta." Jurnal Nusantara Aplikasi Manajemen Bisnis 6(1):1-13. doi: https://doi.org/10.29407/nusamba.v6i1.14533. 
Jurnal Nusantara Aplikasi Manajemen Bisnis

Vol. 6 No.1 Tahun 2021

E-ISSN : 2528-0929 P-ISSN : 2549-5291

\section{Pendahuluan}

Perkembangan teknologi informasi dan internet pada era zaman yang sudah maju seperti saat ini memberikan kemudahan bagi masyarakat untuk memenuhi kebutuhan hidupnya. Penggunaan media internet akan membantu masyarakat untuk memperoleh informasi tanpa harus bertemu secara langsung dengan pihak yang dituju, memberikan ruang kepada konsumen untuk menyampaikan opini dan pendapat terkait dengan produk dan memungkinkan perusahaan untuk memanfaatkannya sebagai media promosi karena internet memiliki jangkauan yang luas (Chan \& Ngai, 2011). Sistem pembayaran nontunai pada kegiatan e-commerce dinilai telah memiliki beberapa kelebihan yang tidak dimiliki ketika melakukan transaksi secara konvensional, diantaranya dapat dilihat dari sisi kemudahan yang diperoleh oleh konsumen, manfaat dan nilai produk atau layanan yang dirasakan konsumen sehingga manfaat inilah yang mendorong konsumen berpindah menggunakan pembayaran non-tunai dalam kegiatan bertransaksi (Adi et al., 2018). Sebagai salah satu aplikasi terkemuka, pertumbuhan jumlah pengguna aplikasi Go-Pay yang luar biasa cepat seperti saat ini tidak terlepas dari peranan pelanggan yang merasa puas dengan Gopay untuk ikut memperkenalkan baik layanan maupun produk melalui Elektronik Word of Mouth (Soliana \& Pratomo, 2016). Pada Oktober 2020, transaksi GoPay sudah meningkat 2,7 kali dibanding sebelum pandemi, dan jumlah merchant yang berkolaborasi dengan GoPay juga_meningkat_80\%, menjadi 900 ribu pada tahun ini; fenomena ini, disamping masih sedikitnya penelitian pada perilaku konsumen pada bidang penggunaan uang non-tunai menjadi dasar penggunaan GoPay dalam penelitian ini. Secara umum, Gopay dapat diartikan sebagai uang elektronik untuk kegiatan beragam pembayaran dan transaksi keuangan yang dilakukan konsumen dalam bentuk aplikasi yang menjadi satu dengan aplikasi Gojek. Selain itu, pesatnya penggunaan uang non-tunai dan berkembangnya komunitas digital dan peran media sosial yang makin intens, menyebabkan kegiatan konsumen yang puas dan ingin berbagi opini menjadi berkembang pada mulai populernya $e$-WOM, yakni penggunaan teknologi digital dan komunitas media sosial elektronik untuk saling menerima dan membagi kegiatan word of mouth. Makin populernya kegiatan ini menjadi bagian dari penelitian ini, yang ingin mengetahui hubungan kepuasan seseorang pada kemungkinan ia melakukan kegiatan $e$-WOM.

Kebaharuan dari penelitian ini adalah dengan memasukan variabel gender sebagai variabel moderasi dan mengubah objek penelitian yaitu Gopay. Beberapa studi telah membuktikan bahwa ada perbedaan signifikan antara pria dan wanita terkait dengan pengalaman dan ekspresi emosi (Stan, 2015).

Beberapa variabel yang akan dibahas untuk menyusun sebuah model penelitian:

\section{Electronic Word of Mouth (e-WOM)}

Bentuk kegiatan pemasaran yang efektif dan cepat dalam upaya mempengaruhi keputusan seseorang baik secara online maupun offline dibandingkan dengan sumber informasi lainnya yaitu dilakukan melalui Word of Mouth (Goyette, Ricard, Bergeron, \& Marticotte, 2010). Informasi yang telah dibutuhkan oleh konsumen pada saat ini dapat dengan mudah diakses melalui media sosial internet secara online. $e$-WOM

De Quelyu, Valinda Carolina, and Singgih Santoso. 2021. "Peranan Customer Satisfaction Dan Customer Commitment Terhadap E-WOM Dalam Pengguna Aplikasi Gopay Di Yogyakarta." Jurnal Nusantara Aplikasi Manajemen Bisnis 6(1):1-13. doi: https://doi.org/10.29407/nusamba.v6i1.14533. 


\section{Jurnal Nusantara Aplikasi Manajemen Bisnis}

Vol. 6 No.1 Tahun 2021

E-ISSN : 2528-0929 P-ISSN : 2549-5291

dipergunakan oleh konsumen untuk megungkapkan pendapatnya mengenai produk berupa barang maupun jasa atau perusahaan melalui media internet dan dianggap lebih efektif apabila dibandingkan dengan Word of Mouth (WOM) yang masih tergolong tradisional melalui offline (Jalilvand \& Samiei, 2012). $e$-WOM merupakan komentar atau rekomendasi yang dibuat oleh konsumen berdasarkan dari pengalaman konsumen dan memiliki pengaruh yang kuat terhadap pengambilan keputusan yang nantinya akan dilakukan oleh konsumen lainnya (Soliana \& Pratomo, 2016). Media yang paling sering dipergunakan untuk mendukung kegiatan $e$-WOM bagi perusahaan atau konsumen yaitu melalui media sosial (Wang et al., 2016). Keterikatan emosional dan rasa ingin memiliki berperan penting untuk mendorong konsumen dalam memberikan ulasan hal positif yang terkait produk maupun jasa melalui $e$-WOM (Lee \& Cheung, 2014).

\section{Customer Commitment}

Untuk menciptakan e-WOM maka dibutuhkan komitmen pelanggan untuk memelihara hubungan yang akan berlangsung secara terus menerus dalam jangka waktu yang panjang (Yaqub et al., 2015). Sebuah Komitmen akan muncul dan berperan sebagai hasil dari persamaan nilai, kepercayaan dan keyakinan yang muncul dari dalam diri pelanggan, sekaligus terdapatnya hubungan yang bernilai dan tidak bisa tergantikan, sehingga menumbuhkan rasa motivasi untuk bekerja sama sekaligus berupaya untuk mempertahankan hubungan agar dapat terus berjalan dengan baik. Komitmen pelanggan dapat diukur dengan menggunakan tiga komponen pengukuran, yaitu affective commitment, continuance commitment, dan normative coomitment. Komitmen pelanggan merupakan suatu ikatan yang telah dimiliki oleh seseorang untuk terus mempergunakan layanan dengan tidak lagi beralih kepada penyedia layanan yang lainnya baik layanan produk maupun jasa.

\section{Customer Satisfaction}

Kepuasan pelanggan merupakan tingkat perasaan seseorang setelah membandingkan kinerja atau hasil yang telah dia rasakan dibandingkan dengan harapannya (Kotler \& Keller, 2016). Untuk dapat menciptakan Electronic Word of Mouth (e-WOM) dengan baik dan benar, maka perusahaan barang maupun jasa harus dapat menciptakan sekaligus mempertahankan kepuasan dari pelanggannya. Kepuasan pelanggan akan muncul setelah pelanggan sudah merasakan dan membandingkan pengalaman yang mereka lalui ketika telah selesai menggunakan produk atau jasa dengan apa yang diharapkan (Fullerton, 2011). Berdasarkan hasil penelitian dari (Sumaedi et al., 2015), diperoleh hasil bahwa peranan $e$-WOM dalam pemasaran produk atau jasa adalah sangat penting. Media online dan media sosial merupakan sarana yang efektif dalam menyampaikan ulasan dan rekomendasi tentang produk dan layanan karena dapat menjangkau konsumen secara global dengan cepat dan mudah.

De Quelyu, Valinda Carolina, and Singgih Santoso. 2021. "Peranan Customer Satisfaction Dan Customer Commitment Terhadap E-WOM Dalam Pengguna Aplikasi Gopay Di Yogyakarta.” Jurnal Nusantara Aplikasi Manajemen Bisnis 6(1):1-13. doi: https://doi.org/10.29407/nusamba.v6i1.14533. 


\section{Jurnal Nusantara Aplikasi Manajemen Bisnis}

Vol. 6 No.1 Tahun 2021

E-ISSN : 2528-0929 P-ISSN : 2549-5291

\section{Gender (variabel moderasi)}

Beberapa studi telah membuktikan bahwa ada perbedaan signifikan antara pria dan wanita terkait dengan pengalaman dan ekspresi emosi, serta proses informasi dimana pria lebih analitis sedangkan wanita cenderung lebih memiliki sikap subyektif (Stan, 2015). Perbedaan antara pria dan wanita sebagian berasal dari faktor biologis dan sebagian dari pengalaman sosialisasi; pria lebih didorong oleh norma sosial yang membutuhkan pengendalian, keahlian dan self-efficacy untuk mencapai tujuan pribadi, sedangkan wanita lebih diarahkan oleh kepeduliannya akan diri dan orang lain serta dorongan untuk berafiliasi dan membina hubungan yang harmonis dengan orang lain.

Beberapa penelitian terdahulu berikut terkait hubungan beberapa variabel di atas:

Didalam penelitian yang dilakukan oleh (San-Martín et al., 2016) mereka menemukan bahwa kepuasan pelanggan sangat berpengaruh signifikan terhadap pembentukan $e$-WOM, sedangkan menurut pernyataan dari (Teo \& Soutar, 2012) kepuasan dari pelanggan berperan memediasi terhadap pembentukan $e$-WOM melalui komitmen yang afektif, sehingga kepuasan dan komitmen pelanggan merupakan faktor yang menetukan terbentuknya $e$-WOM. Penelitian lain juga menyebutkan bahwa kepuasan pelanggan dan komitmen pelanggan yang dirasakan berpengaruh signifikan terhadap perilaku $e$-WOM (Oktaviani et al., 2019; Renfree et al., 2016).

Beberapa peneliti melaporkan adanya ikatan yang kuat, yang merupakan akar komitmen pelanggan, seiring dengan perasaan "kewajiban untuk tidak pergi" dan perasaan bersalah jika terdapat pemutusan hubungan atau terminasi (Čater \& Čater, 2010; Nusair et al., 2012). Penelitian lain juga menunjukkan bahwa kepuasan konsumen berpengaruh terhadap pembentukan WOM melalui komitmen pelanggan (Rahmawaty, 2011; Teo \& Soutar, 2012). komitmen pelanggan afektif juga memiliki dampak yang signifikan pada $e$ WOM karena komitmen pelanggan menunjukkan keinginan untuk memelihara hubungan (Evanschitzky, H. Ramaseshan, B. Woisetschläger, 2011). Juga (Sumaedi et al., 2015) berpendapat bahwa komitmen pelanggan dapat dipergunakan untuk memprediksi perilaku $e$-WOM. Penelitian lain menyebutkan efek positif dari tingginya $e$-WOM, yakni menaikkan kesadaran akan merek serta keinginan membeli produk (Syahrivar \& Ichlas, 2018).

De Quelyu, Valinda Carolina, and Singgih Santoso. 2021. "Peranan Customer 
Vol. 6 No.1 Tahun 2021

E-ISSN : 2528-0929 P-ISSN : 2549-5291

Dari pembahasan di atas, dapat dikemukakan model penelitian:

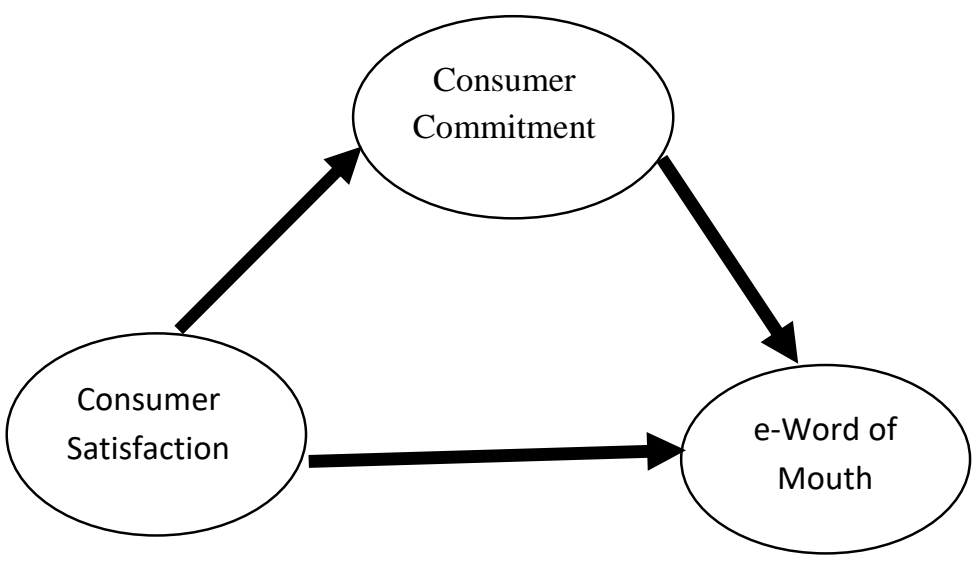

Gambar 1. Model Penelitian

Hipotesis yang dikembangkan dari model di atas:

H1: Customer satisfaction berpengaruh positif terhadap e-WOM

$\mathrm{H} 2$ : Customer satisfaction berpengaruh positif terhadap customer commitment

H3: Customer commitment berpengaruh positif terhadap $e$-WOM

$\mathrm{H} 4$ : Gender mampu memoderasi variabel customer satisfaction, customer commitment dan e-WOM; variabel gender diperkirakan dapat memodifikasi kekuatan hubungan antara variabel customer satisfaction dengan variabel customer commitment, memodifikasi kekuatan hubungan antara variabel customer satisfaction dengan e-WOM dan memodifikasi kekuatan hubungan variabel customer commitment dengan $e$-WOM.

\section{Metode}

Desain penelitian adalah metode survey dengan menggunakan kuisioner. Kuesioner terdiri dari dua bagian, yakni profil responden (jenis kelamin, usia, tingkat pendidikan, pekerjaan, besar top up Gopay dalam satu bulan, rata-rata frekuensi melakukan top up Gopay dalam satu bulan dan total penghasilan dalam satu bulan) dan variabel penelitian yang disajikan dalam bentuk pertanyaan tertutup. Objek penelitian yang akan digunakan pada penelitian ini adalah aplikasi Gopay. Teknik pengambilan sampel pada penelitian ini menggunakan teknik purposive random sampling, dengan kriteria responden adalah mereka yang selama ini telah menggunakan aplikasi Gopay secara rutin di provinsi Daerah Istimewa Yogyakarta, terbiasa melakukan transaksi non-tunai untuk pemenuhan kebutuhan mereka, serta dalam masa pandemi Covid-19 ini berusaha untuk menghindar dari kerumunan orang banyak dalam kegiatan pemenuhan kebutuhan mereka. Setelah data terkumpul, akan dilakukan pengolahan data dengan tujuan untuk menguji hipotesishipotesis yang ada dalam model penelitian. Penelitian menggunakan metode structural equation model (SEM), dengan jumlah sampel penelitian yang ideal berjumlah antara 100400 sampel (Hair et al., 2014). Dalam kegiatan penelitian ini peneliti mengumpulkan sejumlah 377 sampel yang telah valid dan tidak ada data yang hilang.

De Quelyu, Valinda Carolina, and Singgih Santoso. 2021. "Peranan Customer Satisfaction Dan Customer Commitment Terhadap E-WOM Dalam Pengguna Aplikasi Gopay Di Yogyakarta.” Jurnal Nusantara Aplikasi Manajemen Bisnis 6(1):1-13. doi: https://doi.org/10.29407/nusamba.v6i1.14533. 
Vol. 6 No.1 Tahun 2021

E-ISSN : 2528-0929 P-ISSN : 2549-5291

\section{Definisi Operasional dan Pengukuran Indikator}

Definisi operasional dalam penelitian ini adalah customer satisfaction, customer comitment dan e-WOM. Kepuasan pelanggan dapat diartikan dengan penilaian menyeluruh seseorang setelah mengkonsumsi sebuah produk atau jasa dari merek tertentu (San-Martín et al., 2016). Konstruk customer satisfaction mempunyai indikator konsumen puas dengan mengguakan aplikasi Gopay, konsumen puas dengan manfaat aplikasi Gopay, konsumen puas dengan layanan yang terdapat dalam aplikasi Gopay, konsumen puas bertransaksi dengan menggunakan aplikasi Gopay, serta konsumen puas dengan kecepatan waktu loading aplikasi Gopay dalam berkomunikasi dengan pelanggan, khususnya waktu melakukan pemesanan dan tanggapan dari Gopay (Oktaviani et al., 2019; San-Martín et al., 2016).

Sedangkan konstruk komitmen pelanggan dapat diartikan sebagai janji implisit atau eksplisit dari kesinambungan hubungan di antara pihak-pihak yang terlibat dalam kegiatan pertukaran (Bansal et al., 2004). Konstruk Komitmen Pelanggan tersebut dapat diukur dengan indikator (Bansal et al., 2004) pelanggan merasa menggunakan aplikasi Gopay mendukung aktivitas sehari-hari, Pelanggan akan terus menggunakan aplikasi Gopay, Pelanggan bangga menggunakan aplikasi Gopay dalam melakukan sebuah transaksi, dan pelanggan percaya bahwa aplikasi Gopay adalah aplikasi favorit daripada metode pembayaran online lainnya.

Sedangkan konstruk $e$-WOM dapat diartikan sebagai pertukaran, aliran informasi, isi komunikasi, atau isi percakapan antara dua individu; dalam konteks $e$-WOM, maka kegiatan tersebut berlangsung dengan menggunakan media elektronik, seperti media sosial elektronik (Goyette et al., 2010). Konstruk $e$-WOM diukur dengan indikator pelanggan berbicara mengenai layanan aplikasi Gopay kepada teman melaui media sosial, pelanggan berinteraksi dengan sesama pengguna aplikasi Gopay melalui media sosial, pelanggan selalu menyarankan kepada teman untuk bertransaksi menggunakan aplikasi Gopay, serta pelanggan bersedia berbagi pengalaman menggunakan aplikasi Gopay dengan teman melalui media sosial. (Goyette et al., 2010; Nusair et al., 2012).

Setelah data terkumpul, akan digunakan software AMOS untuk proses pengujian measurement model dan structural model, dengan kriteria uji berikut ini:

Tabel 1. Kriteria Uji Fit Structural Equation Model (SEM)

\begin{tabular}{ll}
\hline Kriteria Indeks Ukuran & Nilai Rekomendasi \\
\hline CMIN/df & $\square 2,00$ \\
\hline Goodness-of-fit index (GFI) & $\geq 0,90$ \\
\hline $\begin{array}{l}\text { Adjusted Goodness-of-fit index } \\
\text { (AGFI) }\end{array}$ & $\geq 0,80$ \\
\hline $\begin{array}{l}\text { Root mean square error of } \\
\text { approximation (RMSEA) }\end{array}$ & $\leq 0,08$ \\
\hline \multicolumn{1}{l}{ Sumber : (Hair et al., 2014) } &
\end{tabular}

De Quelyu, Valinda Carolina, and Singgih Santoso. 2021. "Peranan Customer 
Jurnal Nusantara Aplikasi Manajemen Bisnis

Vol. 6 No.1 Tahun 2021

E-ISSN : 2528-0929 P-ISSN : 2549-5291

\section{Hasil dan Pembahasan}

3.1. Analisis Profil Responden

Berikut hasil dari penyebaran kuesioner yang telah dilakukan:

Tabel 2

Profil responden

\begin{tabular}{|c|c|c|c|}
\hline No & Variabel & Keterangan & $\%$ \\
\hline \multirow[t]{2}{*}{1} & Gender & Pria & 51.0 \\
\hline & & Wanita & 49.0 \\
\hline \multirow[t]{4}{*}{2} & Usia & $>20-25$ tahun & 11.0 \\
\hline & & $>25-30$ tahun & 42.0 \\
\hline & & $>30-35$ tahun & 35.0 \\
\hline & & $>35$ tahun & 12.0 \\
\hline \multirow[t]{4}{*}{3} & Pendidikan & s/d SMU & 3.6 \\
\hline & & D3 & 13.6 \\
\hline & & Sarjana & 73.0 \\
\hline & & Pasca Sarjana & 9.8 \\
\hline \multirow[t]{5}{*}{4} & Pekerjaan & PNS/POLRI & 38.0 \\
\hline & & Pegawai Swasta & 42.4 \\
\hline & & Wiraswasta & 17.2 \\
\hline & & Pelajar/Mahasiswa & 2.0 \\
\hline & & Ibu Rumah Tangga & 0.4 \\
\hline \multirow[t]{4}{*}{5} & Penghasilan & $>\operatorname{Rp} 2.000 .000-\mathrm{Rp} 3.000 .000$ & 24.4 \\
\hline & & > Rp 3.000.000-Rp 4.000.000 & 36.8 \\
\hline & & $>$ Rp 4.000.000-Rp 5.000.000 & 31.2 \\
\hline & & $>\operatorname{Rp} 5.000 .000$ & 7.6 \\
\hline \multirow[t]{4}{*}{6} & Besar Top-up & $>\operatorname{Rp} 10.000$ - Rp 50.000 & 5.2 \\
\hline & & >Rp 50.000 - Rp 100.000 & 39.6 \\
\hline & & $>$ Rp 100.000 - Rp 150.000 & 46.0 \\
\hline & Frekuensi Top & $>\operatorname{Rp} 150.000$ & 9.2 \\
\hline \multirow[t]{4}{*}{7} & Up dalam & Satu kali & 22.0 \\
\hline & sebulan & Dua kali & 59.6 \\
\hline & & Tiga kali & 16.4 \\
\hline & & Lebih dari tiga kali & 2.0 \\
\hline
\end{tabular}

Sumber: Data Primer

Dari tabel di atas terlihat mayoritas responden adalah responden laki-laki, dengan rentang usia mayoritas adalah > 25-30 tahun yaitu sebesar (42.4\%), dengan pendidikan mayoritas responden berpendidikan Sarjana sebesar 73.2\%, dengan mayoritas bekerja sebagai pegawai (42.4\%). Terkait dengan besar Top-up Gopay yang dilakukan oleh responden mayoritas responden melakukan Top-up Gopay sebesar >Rp 100.000-Rp 150.000 dengan prosentase (46\%), serta sebagian besar responden melakukan Top-up pada aplikasi Gopay dalam satu bulan yaitu sebanyak dua kali (59.6\%). Terkait besar penghasilan yang dimiliki oleh responden dalam penelitian ini mayoritas responden bepenghasilan sejumlah > Rp 3.000.000-4.000.000 dengan prosentase (36.8\%). Dari data

De Quelyu, Valinda Carolina, and Singgih Santoso. 2021. "Peranan Customer Satisfaction Dan Customer Commitment Terhadap E-WOM Dalam Pengguna Aplikasi Gopay Di Yogyakarta.” Jurnal Nusantara Aplikasi Manajemen Bisnis 6(1):1-13. doi: https://doi.org/10.29407/nusamba.v6i1.14533. 
Jurnal Nusantara Aplikasi Manajemen Bisnis

Vol. 6 No.1 Tahun 2021

E-ISSN : 2528-0929 P-ISSN : 2549-5291

diatas dapat disimpulkan bahwa perilaku konsumen Gopay saat ini menempatkan Gopay hanya sebagai penunjang atau pendukung untuk melakukan aktivitas sehari-hari seperti membeli makan (Gofood), membeli pulsa dan membayar transportasi online Gojek dan Gocar. Hal ini dapat terlihat dari jumlah nominal mayoritas yang responden keluarkan saat melakukan Top-up Gopay yaitu hanya berkisar antara Rp 100.000 - Rp 150.000 dengan responden mayoritas melakukan Frekuensi Top-up dalam satu bulan yaitu sebanyak dua kali. Jika dikaitkan dengan teori kebutuhan Abraham Maslow maka posisi dari Gopay di benak responden yaitu berada pada posisi fisik/fisiologis. Dengan demikian saat ini Gopay dapat digunakan oleh semua kalangan masyarakat namun Gopay belum bisa digunakan untuk menopang kebutuhan selain kebutuhan fisiologis contohnya untuk membeli mesin cuci sepeda motor dan lain-lain sehingga Gopay belum bisa menggapai sasaran yang lebih spesifik misalnya masyarakat elit.

\subsection{Hasil Kriteria Goodnees-of-Fit}

Menggunakan software AMOS, model penelitian akan diuji dengan tampilan:

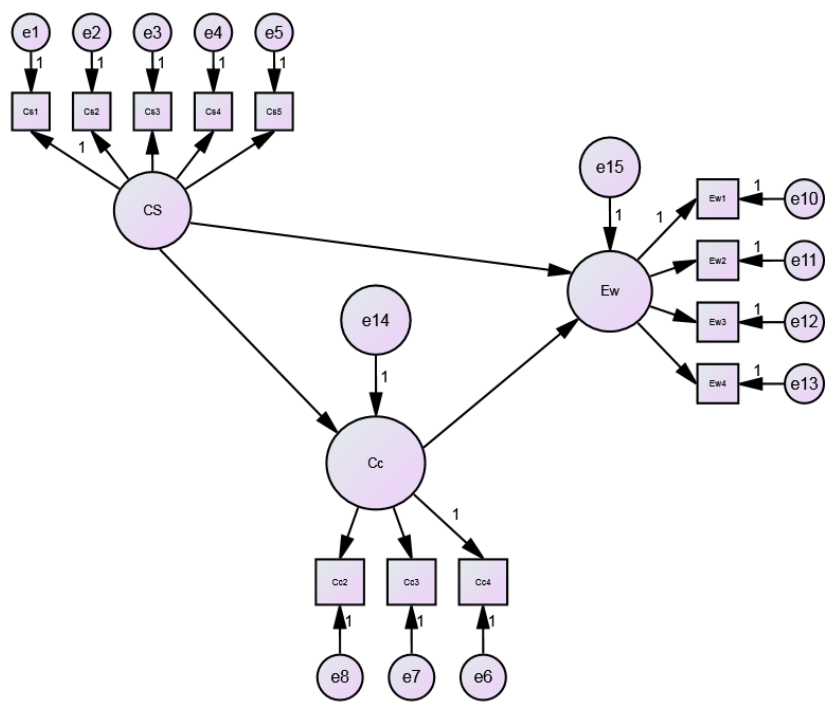

Dengan melakukan sejumlah modifikasi untuk memperbaiki hasil penghitungan pengujian model, dan dengan melakukan evaluasi kriteria godness-of-fit didapatkan hasil sebagai berikut:

Tabel 3. Hasil Uji Fit Structural Equation Model (SEM)

\begin{tabular}{lll}
\hline Kriteria Indeks Ukuran & Nilai & Keterangan \\
\hline CMIN/DF & 4.466 & Baik \\
$\begin{array}{l}\text { Goodness-of-fit index (GFI) } \\
\text { Adjusted Goodness-of-fit index }\end{array}$ & 0,889 & Moderat \\
$\begin{array}{l}\text { (AGFI) } \\
\text { Root mean square error of }\end{array}$ & 0,808 & Moderat \\
approximation (RMSEA) & 0,118 & Moderat \\
\hline \multicolumn{2}{l}{ Sumber : Hasil Pengolahan Data (terlampir) } & \\
\hline
\end{tabular}

De Quelyu, Valinda Carolina, and Singgih Santoso. 2021. "Peranan Customer

Satisfaction Dan Customer Commitment Terhadap E-WOM Dalam Pengguna Aplikasi Gopay Di Yogyakarta.” Jurnal Nusantara Aplikasi Manajemen Bisnis 6(1):1-13. doi: https://doi.org/10.29407/nusamba.v6i1.14533. 
Vol. 6 No.1 Tahun 2021

E-ISSN : 2528-0929 P-ISSN : 2549-5291

Hasil uji goodness-of-fit model menggunakan program AMOS menunjukkan hasil nilai CMIN/DF sebesar $4.466<5.00$, nilai GFI sebesar $0.889>0.90$, nilai AGFI sebesar $0.808>0.80$, dan nilai RMSEA sebesar $0.118<0.08$. Melalui hasil diatas maka dapat ditarik sebuah kesimpulan bahwa konstruk penelitian ini dapat diterima karena telah memenuhi beberapa indikator kriteria goodness-of-fit, khususnya besaran CMIN/DF.

\section{Hasil Uji Hipotesis}

Uji Hipotesis pada penelitian ini dilakukan dengan cara membandingkan nilai $\mathrm{P}$ dengan 0.05. Apabila nilai $\mathrm{P}$ lebih kecil daripada 0.05 maka hipotesis yang dibangun dalam penelitian terdukung atau dapat diterima.

Tabel 4. Hasil Uji Hipotesis

\begin{tabular}{llll}
\hline Hipotesis & Hubungan & Probability & Hasil \\
\hline H1 & Customer Satisfaction $\square e$-WOM & 0,002 & Diterima \\
H2 & Customer Satisfaction $\square$ Customer Commitment & 0,000 & Diterima \\
H3 & Customer Commitment $\square e$-WOM & 0,000 & Diterima \\
\hline
\end{tabular}

Dari tabel di atas terlihat semua besaran probability memperoleh hasil di bawah 0,05. Dengan demikian dapat dinyatakan bahwa hipotesis yang dibangun dalam penelitian (H1, H2, dan $\mathrm{H} 3$ ) dapat diterima. Variabel customer satisfaction secara positif dan signifikan berpengaruh terhadap variabel $e$-WOM dan variabel customer commitment. Dan variabel customer commitment secara positif dan signifikan berpengaruh terhadap variabel $e$-WOM.

Hasil penelitian menunjukkan semakin tinggi kepuasan yang diterima oleh pelanggan aplikasi Gopay maka akan semakin meningkatkan komitmen dari pelanggan untuk terus menggunakan aplikasi Gopay. Hasil penelitian ini sejalan dengan penelitian yang dilkukan oleh (Rahmawaty, 2011) saat melakukan survei kepuasan di Bank Syari'ah; dia menyimpulkan adanya kepuasan dan ketidakpuasan terhadap suatu produk atau jasa akan berpengaruh pada pola perilaku selanjutnya; apabila nasabah (pelanggan) puas, maka kemungkinan besar dia akan membeli produk atau jasa yang sama. Penelitian ini juga sejalan dengan penelitian yang dilakukan oleh (Alkilani et al., 2012; Çera et al., 2018; Serra-Cantallops et al., 2018).

Hasil penelitian juga menunjukkan bahwa customer satisfaction berpengaruh signifikan terhadap $e$-WOM pada pengguna aplikasi Gopay yang ada di kota Yogyakarta. Pelanggan yang puas akan terdorong untuk mengkomunikasikan kegunaan aplikasi Gopay kepada rekan-rekannya melalui smartphone yang telah dimiliki baik melalui komunikasi (chatting) maupun membagikan pengalaman ketika menggunakan aplikasi Gopay melalui status pada jejaring media sosial yang disebut dengan $e-W O M$. Hasil penelitian ini serupa dengan hasil dari penelitian yang telah

De Quelyu, Valinda Carolina, and Singgih Santoso. 2021. "Peranan Customer Satisfaction Dan Customer Commitment Terhadap E-WOM Dalam Pengguna Aplikasi Gopay Di Yogyakarta.” Jurnal Nusantara Aplikasi Manajemen Bisnis 6(1):1-13. doi: https://doi.org/10.29407/nusamba.v6i1.14533. 
Vol. 6 No.1 Tahun 2021

E-ISSN : 2528-0929 P-ISSN : 2549-5291

dilakukan oleh (Wirtz \& Chew, 2002) yang mengatakan bahwa WOM dihasilkan oleh konsumen yang puas dan kekuatan ikat kepuasan konsumen menjadi variabel penting dalam menjelaskan perilaku WOM, demikian juga dengan temuan dari sejumlah penelitian lainnya (Setiawan \& Sayuti, 2017; Syahrivar \& Ichlas, 2018).

Hasil juga menunjukkan customer commitment berpengaruh signifikan terhadap $e$ WOM pada pengguna aplikasi Gopay yang ada di kota Yogyakarta. Responden yang puas dengan pelayanan Gopay akan terus berkomitmen untuk menggunakan layanan aplikasi Gopay dalam mendukung aktivitas sehari-hari responden. Komitmen yang terus dilakukan oleh responden selaku pengguna aplikasi Gopay dengan sendirinya akan mendorong responden untuk berkeinginan menceritakan pengalamannya kepada teman, kerabat maupun orang terdekat untuk ikut menggunakan aplikasi Gopay lewat sejumlah media sosial seperti whatshapp, facebook, instagram, line, twitter dan media sosial lainnya (e-WOM). E-WOM dapat menjadi motor penggerak pengenalan sistem e-money dalam model transaksi finansial yang memungkinkan untuk melakukan transaksi secara online dengan menggunakan smartphone sebagai trend digital dimasa yang akan datang. Hal yang dilakukan oleh responden ini secara tidak langsung bermanfaat untuk perusahaan Gopay karena responden secara tidak langsung sudah membantu mempromosikan manfaat dari aplikasi Gopay dengan bercerita dan mengajak kerabat dan teman-temannya untuk menggunakan apliaksi Gopay melalui $e$-WOM. Hal ini sejalan dengan hasil penelitian yang dilakukan oleh (Moran \& Muzellec, 2017; Oktaviani et al., 2019; Purnasari \& Yuliando, 2015).

Untuk pengujian variabel moderasi gender, digunakan software AMOS dengan fasilitas multiple group, dengan hasil uji pada variabel moderasi gender sebagai berikut:

Tabel 5. Hasil Uji Hipotesis untuk Variabel Gender Laki-Laki Sebagai Moderator

\begin{tabular}{llll}
\hline Hipotesis & Hubungan & Probability & Hasil \\
\hline H4a & Customer Satisfaction $\square$ e-WOM & 0,07 & Ditolak \\
H4b & Customer Satisfaction $\square$ Customer Commitment & 0,000 & Diterima \\
H4c & Customer Commitment $\square e$-WOM & 0,000 & Diterima \\
\hline
\end{tabular}

Untuk gender laki-laki sebagai variabel moderasi, diperoleh hasil hipotesis $\mathbf{H 4 b}$ dan $\mathbf{H 4 c}$ yaitu variabel customer satisfaction terhadap customer commitment dan variabel customer commitment terhadap $e$-WOM memiliki nilai $\mathrm{P}$ dibawah 0.05 yaitu 0.000 sehingga hipotesis diterima. Hasil yang berbeda didapat saat pengujian hipotesis H4a, dimana nilai probabilitas (prob) variabel customer satisfaction terhadap $e$-WOM adalah 0.07, atau di atas nilai batas 0,05, sehingga hipotesis ditolak. Dengan demikian, pelanggan Gopay laki-laki cenderung puas dengan Gopay dan menindaklanjuti kepuasan tersebut dengan berkomitmen untuk terus menggunakan aplikasi Gopay untuk menunjang aktivitas sehari-hari, pelanggan Gopay laki-laki juga cenderung menceritakan Gopay kepada teman, kerabat maupun keluarga melalui $e$ -

De Quelyu, Valinda Carolina, and Singgih Santoso. 2021. "Peranan Customer 
Vol. 6 No.1 Tahun 2021

E-ISSN : 2528-0929 P-ISSN : 2549-5291

WOM karena memang mereka menggunakan Gopay. Namun ketika pelanggan lakilaki tersebut merasa puas terhadap aplikasi Go-Pay, mereka tidak langsung ingin menceritakan kepada orang lain; kepuasan mereka yang bersifat rutin akan secara langsung akan membentuk komitmen pelanggan laki-laki tersebut terlebih dahulu. Baru dari komitmen yang terbentuk dengan kuat, secara perlahan mereka akan melakukan kegiatan e-WOM kepada teman atau kelompok referensi yang lain dalam komunitas mereka.

Tabel 5. Hasil Uji Hipotesis untuk Variabel Gender Wanita sebagai moderator

\begin{tabular}{llll}
\hline Hipotesis & Hubungan & Probability & Hasil \\
\hline H5a & Customer Satisfaction $\square e$-WOM & 0,435 & Diterima \\
H5b & Customer Satisfaction $\square$ Customer Commitment & 0,06 & Diterima \\
H5c & Customer Commitment $\square e$-WOM & 0,159 & Diterima \\
\hline
\end{tabular}

Untuk gender wanita sebagai variabel moderator, diperoleh hasil hipotesis $\mathrm{H} 4 \mathrm{~d}$ dan hipotesis $\mathrm{H} 4 \mathrm{f}$ memperoleh nilai $\mathrm{P}$ diatas 0.05 sehingga hipotesis ditolak. Sedangkan untuk hipotesis $\mathrm{H} 4 \mathrm{e}$ terlihat nilai probabilitas customer satisfaction terhadap customer commitment mendekati nilai 0.05 sehingga hipotesis dapat diterima. Hal ini menunjukkan bahwa pelanggan Gopay wanita cenderung menindaklanjuti kepuasan dalam menggunakan aplikasi Gopay dengan berkomitmen untuk terus menggunakan aplikasi. Namun hal ini tidak mendorong pelanggan wanita membicarakan bahkan mengajak teman, rekan kerja maupun keluarga untuk ikut serta menggunakan aplikasi Gopay melaui aktivitas $e$-Wom. Bagi pelanggan wanita Gopay bukanlah hal yang menarik untuk dibicarakan, Gopay hanya sebuah aplikasi yang fungsional saja. Dari perbedaan dari pelanggan Gopay laki-laki dan wanita ini dapat dismpulkan bahwa variabel gender mampu memoderasi variabel customer satisfaction, customer commitment dan $e$-WOM.

\section{Kesimpulan}

Dari analisis sosio demografi, didapatkan bahwa responden dalam penelitian ini adalah $51.2 \%$ berjenis kelamin laki-laki dan $48.8 \%$ berjenis kelamin perempuan, rentang usia mayoritas berada diantara $>25-30$ tahun (54\%), mayoritas pendidikan responden yaitu Sarjana $(73.2 \%)$, pekerjaan yang digeluti oleh responden mayoritas adalah pegawai swasta (42.4\%), besar Top Up Gopay yang mayoritas dilakukan oleh responden yaitu sebesar $>\mathrm{Rp}$ 100.000-Rp $150.000(46 \%)$, frekuensi responden melakukan top dalam satu bulan mayoritas dua kali $(59.6 \%)$ dan mayoritas responden dalam penelitian ini memiliki penghasilan sebesar Rp 3.000.000-Rp 4.000 .000 (36.8\%). Sedangkan dari uji hipotesis dalam model penelitian dapat disimpulkan bahwa customer satisfaction berpengaruh positif terhadap e-WOM, customer satisfaction berpengaruh positif terhadap customer comitment, customer comitment berpengaruh positif terhadap e-WOM; sedangkan variabel gender mampu memoderasi hubungan variabel customer satisfaction, customer commitment dan e-WOM. Hasil penelitian ini menunjukkan bahwa seorang pelanggan

De Quelyu, Valinda Carolina, and Singgih Santoso. 2021. "Peranan Customer

Satisfaction Dan Customer Commitment Terhadap E-WOM Dalam Pengguna Aplikasi Gopay Di Yogyakarta.” Jurnal Nusantara Aplikasi Manajemen Bisnis 6(1):1-13. doi: https://doi.org/10.29407/nusamba.v6i1.14533. 


\section{Jurnal Nusantara Aplikasi Manajemen Bisnis}

Vol. 6 No.1 Tahun 2021

E-ISSN : 2528-0929 P-ISSN : 2549-5291

yang merasa puas secara berkelanjutan setelah mengkonsumsi sebuah barang atau jasa dari merek tertentu akan cenderung memiliki komitmen kuat terhadap merek tersebut, dan akhirnya pelanggan tersebut secara sadar akan cenderung mempromosikan merek tersebut lewat promosi yang tidak berbayar, yakni kegiatan word of mouth, yang saat ini jika dilakukan lewat media sosial, dinamakan dengan kegiatan $e$-WOM.

\section{Saran}

Karena kepuasan seseorang dapat mendorong terjadinya komitmen, maka GoPay dapat mengupayakan berbagai inovasi layanan baik offline ataupun online kepada konsumen. Pandemi Covid-19 saat ini dapat memunculkan beragam ide layanan tambahan terkait protokol kesehatan, misal menambah pembungkus makanan/barang, driver GoPay membekali diri dengan APD pada situasi tertentu, dan lainnya. Juga layanan bisa ditingkatkan lewa penggunaan contactless payment, perluasan penggunaan $Q R$ Code dengan pelanggan agar mereka merasa aman. Juga GoPay dapat berkolaborasi dengan beberapa perusahaan besar untuk memperbesar jumlah pelanggan dan memperluas cakupan bisnis yang ada; contoh kerjasama GoPay dengan BNI dalam upaya penyaluran kredit kepada UMKM dan kerjasama lainnya.

\section{Daftar Rujukan}

Adi, F., Sumarwan, U., \& Fahmi, I. (2018). Pengaruh Faktor Sikap, Norma Subjektif, Demografi, Sosioekonomi serta Literasi Keuangan Syariah dan Konvensional terhadap Minat Berwirausaha pada Mahasiswa. Al-Muzara'ah, 5(1), 1-20. https://doi.org/10.29244/jam.5.1.1-20

Alkilani, K., Ling, K. C., \& Abzakh, A. A. (2012). The impact of experiential marketing and customer satisfaction on customer commitment in the world of social networks. Asian Social Science, 9(1), 262-270. https://doi.org/10.5539/ass.v9n1p262

Bansal, H. S., Irving, G., \& Shirley, F. (2004). A three-component model of customer commitment to service providers. Journal of the Academy of Marketing Science, 32(3), 234-250. https://doi.org/10.1177/0092070304263332

Čater, T., \& Čater, B. (2010). Product and relationship quality influence on customer commitment and loyalty in B2B manufacturing relationships. Industrial Marketing Management, 39(8), 1321-33.

Çera, G., Cepel, M., Zakutna, S., \& Rozsa, Z. (2018). Gender differences in perception of the university education quality as applied to entrepreneurial intention. Journal of International Studies, 11(3), 147-160. https://doi.org/10.14254/2071-8330.2018/11-3/13

Chan, Y., \& Ngai, E. W. T. (2011). Conceptualising electronic word of mouth activity: An 
Vol. 6 No.1 Tahun 2021

E-ISSN : 2528-0929 P-ISSN : 2549-5291

input-process-output perspective. Marketing Intelligence \& Planning, 29, 488-516. https://doi.org/10.1108/02634501111153692

Evanschitzky, H. Ramaseshan, B. Woisetschläger, D. M. (2011). Consequences of customer loyalty to the loyalty program and to the company. Journal of the Academy of Marketing Science, 40, 625-638. https://doi.org/10.1007/s11747-011-0272-3

Fullerton, G. (2011). Creating advocates: The roles of satisfaction, trust and commitment. Journal of Retailing and Consumer Services, 18(1), 92-100.

Goyette, I., Ricard, L., Bergeron, J., \& Marticotte, F. (2010). e-WOM scale: Word-of-Mouth measurement scale for e-services context. Canadian Journal of Administrative Sciences, 27, 5-23. https://doi.org/10.1002/CJAS.129

Hair, J. F., William C, B., Babin, B. J., \& Anderson, R. E. (2014). Multivariate Data Analysis. Pearson.

Jalilvand, M. R., \& Samiei, N. (2012). The effect of electronic word of mouth on brand image and purchase intention: An empirical study in the automobile industry in Iran. Marketing Intelligence and Planning, 30(4), 460-476. https://doi.org/10.1108/02634501211231946

Kotler, P., \& Keller, K. L. (2016). Marketing Management, 16 ed.. Pearson.

Lee, Z. W.-Y., \& Cheung, C. M.-K. (2014). Problematic Use of Social Networking Sites: The Role of Self-Esteem. International Journal of Business and Information, 9(2), 143-159.

Moran, G., \& Muzellec, L. (2017). eWOM credibility on social networking sites: A framework. Journal of Marketing Communications, 23(2), 149-161. https://doi.org/10.1080/13527266.2014.969756

Nusair, N., Ababneh, R., \& Bae, Y. K. (2012). The impact of transformational leadership style on innovation as perceived by public employees in Jordan.International. Journal of Commerce and Management, 22(3), 182-201.

Oktaviani, N., Astuti, W., \& Firdiansjah, A. (2019). PENGARUH KEPUASAN KONSUMEN TERHADAP PEMBENTUKAN KOMITMEN PELANGGAN DAN eWOM PADA PENGGUNA APLIKASI e-MONEY "OVO." Jurnal Manajemen Dan Pemasaran Jasa, 12(1), 93. https://doi.org/10.25105/jmpj.v12i1.3757

Purnasari, H., \& Yuliando, H. (2015). How Relationship Quality on Customer Commitment Influences Positive e-WOM. Agriculture and Agricultural Science Procedia, 3, 149153. https://doi.org/10.1016/j.aaspro.2015.01.029

Rahmawaty, A. (2011). PENGARUH SERVICE PERFORMANCE, KEPUASAN, TRUST DAN KOMITMEN TERHADAP LOYALITAS NASABAH DI BANK SYARI'AH MANDIRI KUDUS. INFERENSI, Jurnal Penelitian Sosial Keagamaan, 5(1), 53-80.

Renfree, I., Harrison, D., Marshall, P., \& Stawarz, K. (2016). Don't kick the habit: The role 


\section{Jurnal Nusantara Aplikasi Manajemen Bisnis}

Vol. 6 No.1 Tahun 2021

E-ISSN : 2528-0929 P-ISSN : 2549-5291

of dependency in habit formation apps. Dl.Acm.Org, 1.

https://dl.acm.org/citation.cfm?id=2892495

San-Martín, S., Prodanova, J., \& Catalán, B. L. (2016). What makes services customers say "buy it with a mobile phone"? Journal of Services Marketing, 30(6), 601-614.

Serra-Cantallops, A., Ramon-Cardona, J., \& Salvi, F. (2018). The impact of positive emotional experiences on eWOM generation and loyalty. Spanish Journal of Marketing - ESIC, 22(2), 142-162. https://doi.org/10.1108/SJME-03-2018-0009

Setiawan, H., \& Sayuti, A. J. (2017). Effects of service quality, customer trust and corporate image on customer satisfaction and loyalty: an assessment of travel agencies customer in South Sumatra Indonesia. IOSR Journal of Business and Management, 19(5), 31-40.

Soliana, D. S., \& Pratomo, L. A. (2016). ANTESEDEN DARI WORD OF MOUTH. Jurnal Ekonomi, 7(01), 1-10.

Stan, V. (2015). Does Consumer Gender Influence The Relationship Between Consumer Loyalty And Its Antecedents? Journal of Applied Business Research, 31(4), 1593-1604. https://doi.org/10.19030/jabr.v31i4.9339

Sumaedi, S., Juniarti, R. P., \& Bakti, I. G. M. Y. (2015). Understanding trust \& commitment of individual saving customers in Islamic banking: The role of ego involvement. Journal of Islamic Marketing, 6(3), 406-428. https://doi.org/10.1108/JIMA-06-2013-0045

Syahrivar, J., \& Ichlas, A. (2018). The Impact of Electronic Word of Mouth (E-WoM) on Brand Equity of Imported Shoes: Does a Good Online Brand Equity Result in High Customers' Involvements in Purchasing Decisions?. (AJTM). 11. 57-69. 10.12695/ajtm.2018.11.1.5. The Asian Journal of Technology Management, 11(1), 5769. https://doi.org/10.12695/ajtm.2018.11.1.5

Teo, R., \& Soutar, G. (2012). Word of mouth antecedents in an educational context: A Singaporean study. International Journal of Educational Management, 26(7), 678-695. https://doi.org/10.1108/09513541211263746

Wang, T., Yeh, R. K. J., Chen, C., \& Tsydypova, Z. (2016). What drives electronic word-ofmouth on social networking sites? Perspectives of social capital and self-determination. Telematics and Informatics, 33(4), 1034-1047. https://doi.org/10.1016/j.tele.2016.03.005

Wirtz, J., \& Chew, P. (2002). The effects of incentives, deal proneness, satisfaction and tie strength on word-of-mouth behaviour. International Journal of Service Industry Management, 13(2), 141-162. https://doi.org/10.1108/09564230210425340

Yaqub, M. Z., Malik, A., \& Shah, H. (2015). The roles of satisfaction, trust and commitment in value-creation in strategic networks. European Journal of Economics, Finance and Administrative Sciences, 18(1), 133-145.

De Quelyu, Valinda Carolina, and Singgih Santoso. 2021. "Peranan Customer

Satisfaction Dan Customer Commitment Terhadap E-WOM Dalam Pengguna Aplikasi Gopay Di Yogyakarta." Jurnal Nusantara Aplikasi Manajemen Bisnis 6(1):1-13. doi: https://doi.org/10.29407/nusamba.v6i1.14533. 